\title{
Effect of Various Pretreatment for Extracting Intracellular Lipid from Nannochloropsis oculata under Nitrogen Replete and Depleted Conditions
}

\author{
Duraiarasan Surendhiran and Mani Vijay \\ Bioelectrochemical Laboratory, Department of Chemical Engineering, Faculty of Engineering and Technology, \\ Annamalai University, Annamalai Nagar, Tamil Nadu 608002, India
}

Correspondence should be addressed to Mani Vijay; drmvijay2009@gmail.com

Received 25 November 2013; Accepted 7 January 2014; Published 4 March 2014

Academic Editors: M. Hamdi and M. Kostoglou

Copyright (C) 2014 D. Surendhiran and M. Vijay. This is an open access article distributed under the Creative Commons Attribution License, which permits unrestricted use, distribution, and reproduction in any medium, provided the original work is properly cited.

\begin{abstract}
Microalga is one of the most compelling microbial biomasses for biodiesel production. Various pretreatment processes, namely, enzyme treatment, lysis by acid, ultrasonicator, microwaves, autoclave, and $40 \% \mathrm{NaCl}$, for nitrogen replete and depleted algal cultures of Nannochloropsis oculata had been carried out to check the most feasible and effective technique to disrupt cells for procuring lipids, for which concentrations were determined. Fatty acid composition, essential functional groups, and cell disruption were analyzed by GC-MS, FT-IR Spectroscopy, and Nile Red fluorescent microscopy, respectively. The present investigation showed that lipid yield was higher in nitrogen depleted cells than that in normally nourished cells. GC-MS revealed the presence of major fatty acids-palmitic, oleic, stearic, arachidic, lauric, and linoleic acids. Highest efficiency was found when cells were pretreated using acid for $3 \mathrm{~h}$. The lipid content was calculated as $33.18 \%$ and $54.26 \%$ for nitrogen rich cells and nitrogen starved cells, respectively. This work thus aided in identifying the most eligible pretreatment process to avail lipids from cells, to convert them to eco-friendly and nonpolluting biodiesel.
\end{abstract}

\section{Introduction}

Increasing population and uncontrolled urbanization have created serious problems of energy requirement. Due to a sudden hike in energy consumption, it is anticipated that there would be deterioration in oil reserves by 2050. Continuous use of fossil fuels resulted in effect on environment by increasing greenhouse gas emission leads to climatic changes [1]. Therefore, there is a current demand to find out the alternative eco-friendly fuel against petrodiesel. Biodiesel has been considered as a major alternative for fossil fuel, as it is a biodegradable, renewable and nontoxic fuel [2]. Fatty acid methyl esters originating from vegetable oils and animal fats are known as biodiesel. It does not contribute net carbon dioxide or sulfur to the atmosphere and emits less gaseous pollutants than the petrodiesel [3]. Plants and algae are good candidates, as alternative energy sources, as they obtain their energy from the sunlight and build up their biomass by removing carbon dioxide from atmosphere through photosynthesis [4]. Recently, there is much interest in lipid production from microalgae because they have multiple advantages over traditional energy crops [5]. Microalgae have a high photosynthetic efficiency, rapid growth rate, shorter doubling time, and higher biomass production rate and utilize very less land than conventional crops $[6,7]$.

Biodiesel from algae is widely considered as one of the most efficient methods because algae do not compete with food crops [8]. For example, using corn as a feedstock for making ethanol creates a negative competition between human and animal consumption or fuel production [7].

Though algae contain high amount of lipid content, biodiesel production process is not being commercially operated elsewhere; only some companies are involved in commercialization. Since extraction of algal lipids is costly, it is one of the key challenges for the commercial success of algae biofuel [9]. Biodiesel production from microalgae 
consists of the following steps including species selection, cultivation, harvest, and cell disruption. Cell disruption is particularly an important step as cell walls are generally thick and consist of multiple layers [6,9]. Extracting oil from microalgae for biofuel production is one of the principal steps of microalgae-based biodiesel production [10]. Since cell wall and membrane present in algae are formidable barriers to permeation by extraction solvents, cells have to be disrupted prior to extraction [11], which enhances oil recovery. Methods of cell wall disruption and extracting solvents decide the efficiency of oil extraction from microalgae [11].

To make it more economically attractive, a feasible cell disruption method should be established to ensure a low operating cost, high product recovery, and high quality of the recovered lipids. The purpose of this study was to compare and evaluate a range of different physical and chemical treatments on the disruption of cells of marine Nannochloropsis oculata for lipid recovery. Finding the most appropriate method of cell disruption for Nannochloropsis oculata would maximize the lipid concentration and improve the quality of the extracted lipids. Measurements of lipid concentrations were obtained to indicate cell disruption efficiency as a correlating variable [6].

From the literature survey, we have found only few researchers worked on enzymatic cell disruptions, acid hydrolysis, and osmotic shock using $\mathrm{NaCl}$. In this work we had compared different pretreatment process for optimistic extortion of oil from nitrogen availed culture and nitrogen starved culture with the commonly available methods such as ultrasonication, autoclaving, and microwave method. The specific objective of this study was to investigate several pretreatment for loosening the cell wall of microalgae, for intracellular oil extraction and visualizing their cell wall after pretreatment using light microscopy.

\section{Materials and Methods}

2.1. Culture Condition. Nannochloropsis oculata was obtained from CMFRI, Tuticorin, Tamilnadu, India, and cultivated in $25 \mathrm{~L}$ photobioreactor using sterile Walne medium under 5000 lux illuminated with white fluorescent bulb for $12: 12 \mathrm{hr}$ light and dark condition for 15 days. One reactor was filled with nitrogen rich Walne's medium and another medium was supplied with nitrogen for the first 4 days after which the nutrients were added to medium containing nitrogen and medium without nitrogen for scaling up to $25 \mathrm{~L}$.

2.2. Harvesting of Cells. When the culture reached stationary phase, the biomass was harvested by centrifugation at $8500 \mathrm{rpm}$ for $10 \mathrm{~min}$ to get thick algal paste. Then the microalgal paste was rinsed with distilled water to remove residual salts and then dried in hot air oven at $60^{\circ} \mathrm{C}$ for $8 \mathrm{~h}$.

\subsection{Pretreatment of Algal Cells for Oil Extraction}

2.3.1. Acid Lysis of Microalgae. A quantity of $3 \mathrm{~g}$ of dried microalgal biomass was added to sterile sea water, the $\mathrm{pH}$ was reduced to 2.0 with $\mathrm{HCl}$, and the solution was shaken for $1 \mathrm{~h}$, $2 \mathrm{~h}$, and $3 \mathrm{~h}$ using orbital shaker at $180 \mathrm{rpm}$.

2.3.2. Enzymatic Treatment. The microalgal suspension was disrupted with cellulase (Hi Media, Ltd, Mumbai, India). A quantity of $2 \mathrm{~g}$ of dried microalgal biomass was taken in $250 \mathrm{~mL}$ Erlenmeyer flask containing cellulase enzyme solution prepared with $0.1 \mathrm{M}$ sodium citrate buffer and the enzymatic hydrolysis was conducted at $37^{\circ} \mathrm{C}$ for $1 \mathrm{~h}, 2 \mathrm{~h}$, and $3 \mathrm{~h}$. The concentration of cellulase enzyme was $5 \mathrm{mg} \mathrm{L}^{-1}$. The $\mathrm{pH}$ was adjusted to 5.5 with diluted $\mathrm{HCl}$ before disruption. Then cellulase was inactivated by heating at $100^{\circ} \mathrm{C}$ for $10 \mathrm{~min}$.

2.3.3. Thermal Treatment. The heat treatment was performed for $2 \mathrm{~g}$ of biomass using autoclave. In this experiment, the autoclave was maintained at $121^{\circ} \mathrm{C}, 15 \mathrm{lbs}$ pressure for $10 \mathrm{~min}$, $20 \mathrm{~min}$, and $30 \mathrm{~min}$.

2.3.4. Microwave Treatment. This experiment was conducted in the microwave oven (Model-National NN-S557WF) for $5 \mathrm{~min}, 10 \mathrm{~min}$, and $15 \mathrm{~min}$ at $100^{\circ} \mathrm{C}, 900 \mathrm{~W}$, and $2455 \mathrm{MHz}$.

2.3.5. Pretreatment with $40 \% \mathrm{NaCl}$ Solution. The algal dried biomass was treated with $40 \% \mathrm{NaCl}$ solution in an Erlenmeyer flask and kept at $180 \mathrm{rpm}$ in an orbital shaker for 24, 48 , and 72 hrs.

2.3.6. Ultrasonic Treatment. The pretreatment process for microalgal cell wall destruction was also performed with Ultrasonicator (VIBRCEL VX400, Sonic Limited, USA) at $24 \mathrm{kHz}$ at a temperature of $50^{\circ} \mathrm{C}$ for $5 \mathrm{~min}$. The algal biomass was mixed with $15 \mathrm{~mL}$ of sterile distilled water and sonicated at 70 aptitude for $5 \mathrm{~min}, 10 \mathrm{~min}$, and $15 \mathrm{~min}$. To avoid overheating of samples, they were kept in an ice bath during the ultrasonic process. All the experiments were carried out for both microalgal biomass harvested from nitrogen rich and depleted media. After pretreatment, the biomass slurry was subjected to drying to remove excess moisture in hot air oven.

2.4. SEM Analysis. The different pretreated microalgal cells were subjected to morphological analysis to examine cell wall damage. Small amount of sample was taken from the suspension, dried, and observed with Scanning Electron Microscope (SEM).

2.5. Oil Extraction. Cell slurries from acid treatment, enzymatic treatment, ultrasonication, autoclaving, plasmolysis with $40 \% \mathrm{NaCl}$, and microwave treatment were subjected to oil extraction by Bligh and Dyer [12] with slight modification. In brief, the biomass suspension was mixed with chloroform: methanol $(1: 2)$ ratio, vortexed for few minutes, and incubated on ice for 10 minutes. Chloroform was then added, followed by addition of $1 \mathrm{M} \mathrm{HCl}$, and was vortexed again for few minutes. Finally the whole suspension was centrifuged at maximum speed for 2 minutes. Bottom layer containing lipid was transferred into fresh previously weighed beaker. Chloroform was added to reextract the lipid from the aqueous 
sample. The solvent system was evaporated using rotary evaporator at $30^{\circ} \mathrm{C}$. Finally, the lipids from all the disruption methods were analyzed for fatty acid composition analysis using GC-MS.

2.6. Calculation of Oil Yield. The liquid phase was transferred to preweighed flasks. Thereafter, the flasks were then placed in a hot air oven for complete evaporation of the solvent and were weighed again. The total lipid fraction was calculated after obtaining the differences of final and initial flask weights. The lipid concentration was defined as dry weight ratio of extracted lipids to biomass. According to Suganya and Renganathan [8], the oil extraction yield (\%w/w) was determined by the following formula:

$$
\begin{aligned}
& \text { Oil extraction yield (\%) } \\
& \qquad=\frac{\text { Weight of extracted oil }(\mathrm{g})}{\text { Weight of algal biomass }(\mathrm{g})} \times 100 .
\end{aligned}
$$

The extracted oil from untreated algal biomass (from nitrogen rich medium and nitrogen depletion medium) was considered as control for comparing oil pretreated by different extraction techniques.

2.7. FTIR Analysis. A quantity of $50 \mathrm{mg}$ of dried biomass was taken, mixed with $150 \mathrm{mg}$ of KBR powder, and ground well to fine mixture. The mixture was pressed to a disc using a hydraulic press. The disc was subjected to FTIR spectral measurement in the frequency range of $4000-400 \mathrm{~cm}^{-1}$. The algal powder was characterized using a Fourier Transfer Infrared Spectrophotometer (Bruker Optics, GmBH, Germany).

2.8. Intracellular Lipid Identification by Nile Red Staining. It is a specific stain to identify intracellular lipids present in biological samples. A stock solution of Nile Red stain (9diethylamino-5H-benzo $(\alpha)$ phenoxa-phenoxazine-5-one) was prepared according to Mohamady et al. [13]. A quantity of $2.5 \mathrm{mg}$ of Nile Red was dissolved in brown bottle containing $100 \mathrm{~mL}$ of acetone and this was stored at dark. Each $0.5 \mathrm{~mL}$ of microalgae culture broth (both nitrogen rich and nitrogen depletion) was centrifuged at $1500 \mathrm{rpm}$ for 10 minutes and the pellets were washed with sterile distilled water (equal volume) for several times. The cell pellets were then mixed with $0.5 \mathrm{~mL}$ of Nile Red solution incubated for $10 \mathrm{~min}$ at room temperature. After washing with distilled water, the stained cells were observed under fluorescence microscopy.

2.9. Chlorophyll Content Analysis. The chlorophyll a content $(\mathrm{mg} / \mathrm{L})$ was estimated according to $\mathrm{Su}$ et al. [14]. Two milliliters of culture broth was taken in centrifuge tube, ultrasonic for $10 \mathrm{~min}$ in ice bath with two milliliters of $90 \%$ methanol overnight. Then the homogenate was centrifuged at $3000 \mathrm{rpm}$ for $5 \mathrm{~min}$. The supernatant was separated and absorbance was read at 665 and the amount of chlorophyll was calculated using the following formula:

$$
\text { Chlorophyll } a\left(\mathrm{mg} \mathrm{L}^{-1}\right)=13.43 \times \mathrm{OD}_{665} \text {. }
$$

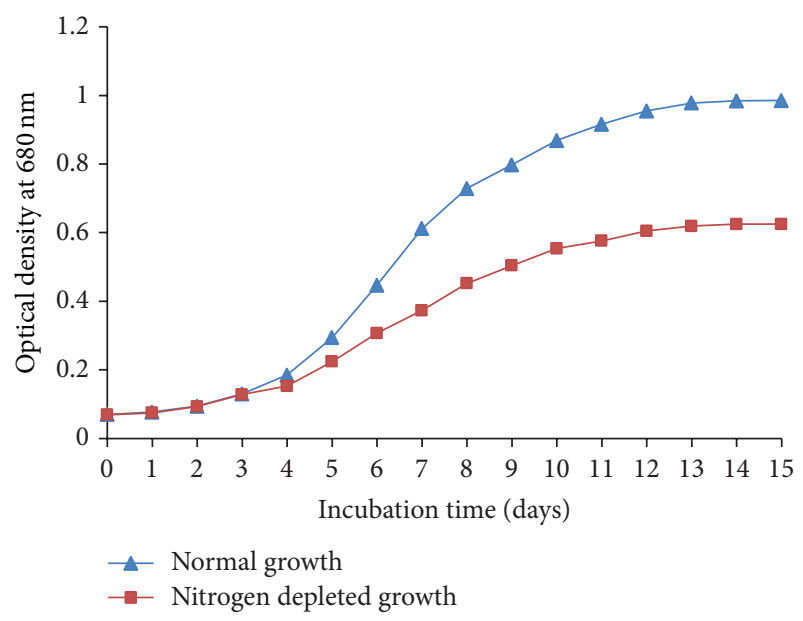

Figure 1: Growth curves of N. oculata grown on Walne's medium with nitrogen replete $\left(\mathrm{N}^{+}\right)$and nitrogen depleted $\left(\mathrm{N}^{-}\right)$conditions.

2.10. Total Carbohydrate and Protein Estimation. The total carbohydrate content was determined with DNS method using glucose as reference and the total protein content was estimated according to Lowry's method [15] using bovine serum albumin as standard.

2.11. Gas Chromatography and Mass Spectroscopic Determination of Fatty Acid Components. Fatty acid compositions of oil extracted from both nitrogen rich and nitrogen depleted cultures were analyzed by Gas Chromatography-Mass Spectrometry (GC-MS-QP 2010, Shimadzu) equipped with VF$5 \mathrm{MS}$ capillary column (30 $\mathrm{mm}$ length, $0.25 \mathrm{~mm}$ diameter, and $0.25 \mu \mathrm{m}$ film thickness). The column temperature of each run was started at $70^{\circ} \mathrm{C}$ for $3 \mathrm{~min}$, then raised to $300^{\circ} \mathrm{C}$, and maintained at $300^{\circ} \mathrm{C}$ for $9 \mathrm{~min}$. GC conditions were as follows: column oven temperature: $70^{\circ} \mathrm{C}$, injector temperature: $240^{\circ} \mathrm{C}$, injection mode split, split ratio: 10 , flow control modelinear velocity, column flow: $1.51 \mathrm{~mL} / \mathrm{min}$, carrier gas-helium (99.9995\% purity), and injection volume: $1 \mu \mathrm{L}$. MS conditions were as follows: ion source temperature: $200^{\circ} \mathrm{C}$, interface temperature: $240^{\circ} \mathrm{C}$, scan range: $40-1000 \mathrm{~m} / \mathrm{z}$, solvent cut time: $5 \mathrm{~min}$, MS start time: $5 \mathrm{~min}$, end time: $35 \mathrm{~min}$, and ionization-EI $(-70 \mathrm{eV})$ and scan speed: 2000.

\section{Results and Discussion}

3.1. Growth Aspects of N. oculata under Normal and Nitrogen Depleted Conditions. The effect of nitrogen on microalgal growth is shown in Figure 1. The algal growth was increased under nitrogen replete condition, whereas some loss in growth was observed during nitrogen limited or starvation condition [16]. A previous study by Alsull and Wan Omar [17] also resulted in a decreasing yield of biomass when algae were grown without nitrogen. Microalgal growth slows down in lack of nitrogen, hence no synthesis of new membrane compounds takes place. Nitrogen is an essential nutrient for algal growth; hence it was added to the nitrogen depleted cells initially. At the 5th day, the medium was supplied without 


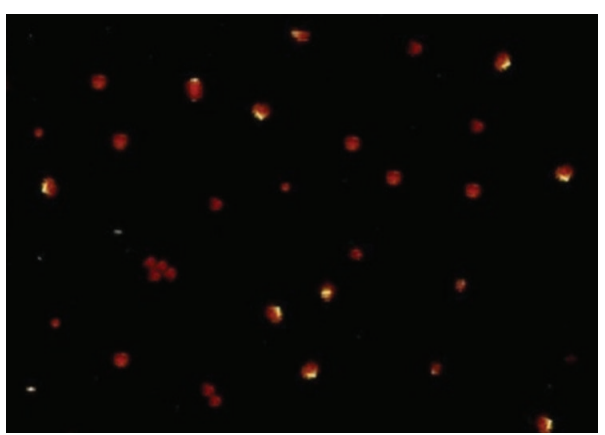

(a)

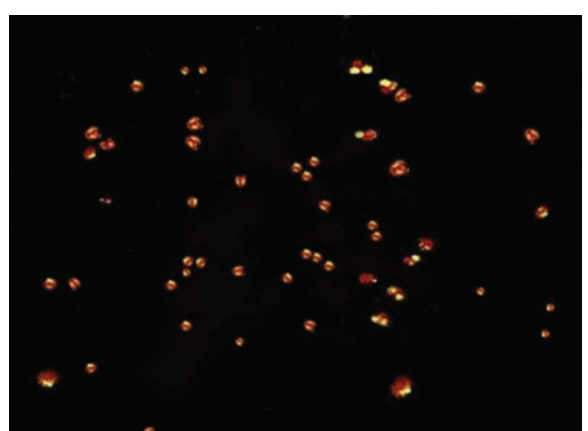

(b)

FIgURE 2: Nile Red stained cells of Nannochloropsis oculata under fluorescent microscope. (a) Normal cells. (b) Nitrogen starved cells.

TABLE 1: Chlorophyll, protein content, and carbohydrate content of N. oculata under nitrogen replete and nitrogen depleted condition.

\begin{tabular}{lcc}
\hline Parameter & $\mathrm{N}^{+}$ & $\mathrm{N}^{-}$ \\
\hline Chlorophyll content $(\mu \mathrm{g} / \mathrm{mL})$ & 9.4 & 7.38 \\
Protein content $(\mu \mathrm{g} / \mathrm{mL})$ & 1.95 & 0.98 \\
Total carbohydrate $(\mu \mathrm{g} / \mathrm{mL})$ & 4.89 & 2.79 \\
\hline
\end{tabular}

$\mathrm{N}^{+}$cells grown in normal medium, $\mathrm{N}^{-}$cells grown in nitrogen depleted medium.

nitrogen to microalgal culture. The nitrogen-rich cells were dark green pigmented, whereas nitrogen depleted culture grew with same color till lag phase and turned yellow green at log and stationary phases. This indicated that nitrogen was essential in synthesis of chlorophyll for photosynthesis which also enhanced growth of microalgae. Similar result was also found in Beal et al. [18] which showed that nitrogen starved algal paste was yellow green in color and healthy sample was dark green.

\subsection{Chlorophyll, Protein, and Total Carbohydrate Analysis.} Chlorophyll and protein contents drastically decreased to half of their actual concentration (Table 1). A similar result was obtained by Alsul and Wan Omar et al. [17] for Tetraselmis sp. and Nannochloropsis sp. The chlorophyll a content was decreased, while the total lipid content increased under nitrogen limitation or starvation condition. In case of total carbohydrate, the content decreased moderately than the protein and chlorophyll. In general, during nitrogen limitation conditions the normal carbohydrate and protein metabolic pathways of cells are reverted to lipid synthesis [19], which leads to high amount of intracellular lipid accumulation in microalgae during nitrogen starvation.

3.3. Nile Red Staining for Lipid Identification. Intracellular lipid droplets of $N$. oculata nitrogen rich cells and nitrogen starved cells were observed by Nile Red staining under fluorescent microscope with excitation at 450-490-nm and emission at 515-nm. Neutral lipid or triglycerides appeared as yellow dots, whereas polar lipid and chlorophyll were stained in red colour. Figure 2 shows that nitrogen starved cells contained more lipid droplets with increased cell size than the normal cells. Ahlgren and Hyenstrand [20] and Hoffman et al. [21] reported that under nitrogen-deficient conditions, algal cells often accumulate a surplus of carbon metabolites as neutral lipids more than polar lipids. These neutral lipids are located as lipid bodies in the cytoplasm of microalgal cells (Figure 2). It was also reported that microalgae respond to the nitrogen starvation condition by degrading nitrogen containing macromolecules and accumulating carbon reserve compounds for the maintenance of cells, such as polysaccharides and fats. Current findings support previous research by Elumalai et al. [22] and Pick and Rachutin-Zalogin [23] mentioned that the Nile Red staining technique was a useful tool for rapid determination of lipids in microalgae.

3.4. FTIR Analysis. Analysis of the microalgal biomass was performed by FTIR-Spectrophotometer. Figure 3 shows the FT-IR spectra of dried biomass sample of normally nourished (Figure 3(a)) and nitrogen depleted cells (Figure 3(b)) of $N$. oculata. Table 2 reveals the various functional groups present in the samples. Bands were attributed to $-\mathrm{CH}$ stretch, protein band, $\mathrm{N}-\mathrm{H}$ and $\mathrm{C}=\mathrm{O}$ stretches of peptide bond, $-\mathrm{CH}_{2}$ stretch of lipids, $\mathrm{C}=\mathrm{O}$ stretch of ester, and $\mathrm{C}-\mathrm{O}-\mathrm{P}, \mathrm{C}-\mathrm{C}$, and $\mathrm{C}-\mathrm{O}$ stretches of polysaccharides. Both spectra were found to be almost matching with slight disparity in peaks. In Figure 3(b), less intensified absorption bands were observed in the region of $1800-800 \mathrm{~cm}^{-1}$, a region specific for carbohydrate and protein, showing a decrease in their content. This could be a notification of carbohydrate metabolism reverting to that of lipids when cells starved from nitrogen. Also, sharp absorption bands in the region of $3100-2800 \mathrm{~cm}^{-1}$ were found in spectrum of nitrogen depleted cells, showing increased lipid content and intensity of the particular band was lesser in nitrogen replete cells. From these spectrograms it was inferred that components present were mostly cis isomers as the bands were between 700 and $3500 \mathrm{~cm}^{-1}$ (Phukan [24], Elumalai et al. [22], and Rukminasari [25]).

3.5. Pretreatment of N. oculata for Oil Extraction. The amount of total oil extracted from $N$. oculata was considered as an indication of the efficiency of different cell disruption methods used. A significant difference was found between 


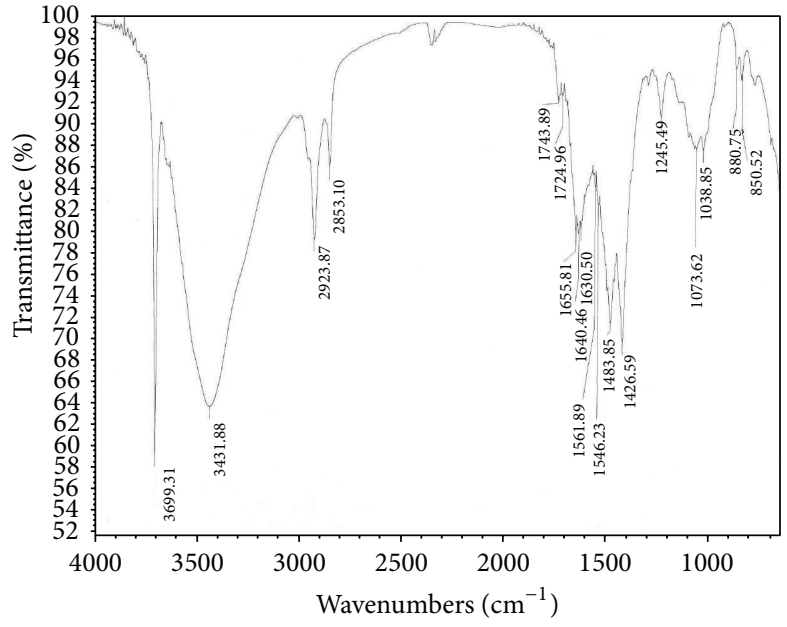

(a)

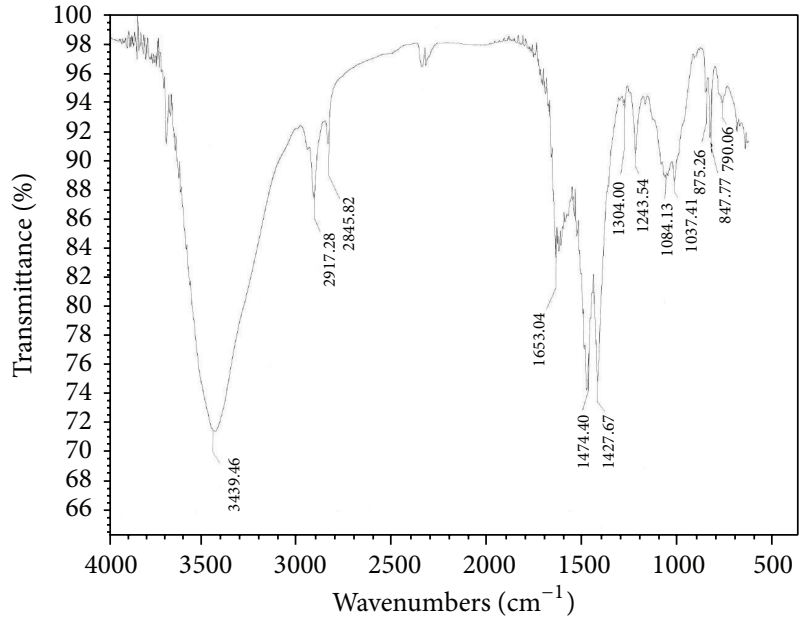

(b)

FIGURE 3: The FTIR spectrum of N. oculata grown under nitrogen depleted (a) and replete conditions (b).

TABLE 2: Representing the functional groups of nitrogen replete and depleted cells of N. oculata.

\begin{tabular}{|c|c|}
\hline Wave numbers $\left(\mathrm{cm}^{-1}\right)$ & Functional groups \\
\hline $3000-2700$ & $\mathrm{C}-\mathrm{H}$ stretching vibrations of $-\mathrm{CH}_{3},>\mathrm{CH}_{2}, \mathrm{CH}, \mathrm{CHO}$ \\
\hline $3600-3300$ & Oleophilic $\mathrm{C}-\mathrm{H}$ stretching vibration, indicating unsaturation \\
\hline 1653.04 & $\mathrm{C}=\mathrm{O}$ of carboxylic acid and derivatives \\
\hline 1743.89 (Figure 3(a)) & $\mathrm{C}=\mathrm{O}$ of ester group \\
\hline $1800-1500$ & Characteristic for proteins \\
\hline $1600-1500$ & Amide II bands, due to $\mathrm{N}-\mathrm{H}$ stretching vibration \\
\hline $1200-900$ & $\begin{array}{l}\mathrm{C}-\mathrm{O}, \mathrm{C}-\mathrm{C}, \mathrm{C}-\mathrm{O}-\mathrm{C}, \mathrm{C}-\mathrm{O}-\mathrm{P} \text { stretching vibrations of polysaccharides } \\
\qquad \mathrm{CH}_{3}, \mathrm{CH}_{2} \text { rocking mode of vibrations }\end{array}$ \\
\hline $3100-2800$ & Presence of lipid \\
\hline 2922.77 (Figure 3(a)), 2924.50 (Figure 3(b)) & $\mathrm{CH}_{2}$ asymmetric stretching in lipid \\
\hline 2851.32 (Figure 3(a)), 2853.23 (Figure 3(b)) & $\mathrm{CH}_{2}$ symmetric stretching in lipid \\
\hline
\end{tabular}

the studied techniques and this study proved that all pretreatment methods were able to disrupt $N$. oculata to release intracellular lipids.

Enzymatic pretreatment was carried out using cellulase enzyme $\left(5 \mathrm{mg} \mathrm{L}^{-1}\right)$ for $8 \mathrm{~h}, 10 \mathrm{~h}$, and $12 \mathrm{~h}$ interval. A maximum efficiency by enzymatic pretreatment was found to be at $12 \mathrm{~h}$ as $32.74 \%$ from nitrogen rich cultures and $51.68 \%$ under nitrogen starvation condition. The microalgal cell wall is made up of polysaccharide mainly comprising cellulose that can be hydrolyzed by the enzyme, cellulase [26]. From the data it was clear that the oil extraction was found to be increased with increasing pretreatment time with cellulase. From the literature, the benefit of using enzyme for hydrolyzing microalgal cell wall was evaluated by Zemke-White et al. [27]. Presently, enzymatic cell wall degradation is not widely practiced in industry because cell lysing enzymes have traditionally been cost prohibitive. Though cost intensive, enzyme degradation is important because the rigid cell wall of algal cell is resistant to mechanical methods that will require excess energy usage and multiple passes through disruption equipment. The cost factor can be overcome by immobilization of enzyme. Moreover, an alga does not have lignin in its cell wall, which is a major advantage to perform enzymatic hydrolysis of its polysaccharide components [4]. Fu et al. [26] had successfully hydrolysed Chlorella sp. using immobilized cellulase with electrospun polyacrylonitrile (PAN) producing reducing sugar. Therefore use of enzyme to lyse algal cell wall might be advantageous as compared to other methods.

Effect of acid treatment was studied at different time periods $-1 \mathrm{~h}, 2 \mathrm{~h}$, and $3 \mathrm{~h}$. During acid lysis treatment of $N$. oculata, at $\mathrm{pH} 2.0$, there was a high effect on oil released at an incubation of $2 \mathrm{~h}$. The marine microalgae have been used as feed for herbivorous fishes worldwide. The researchers believed that many marine herbivorous fishes must possess acidic gastric condition in their stomach to gain access to the intracellular nutrients from algae for their diet [28]. The present study showed that the most efficient cell disruption occurred after $2 \mathrm{~h}$ of incubation giving $33.18 \%$ for nitrogen availed culture and $54.26 \%$ for nitrogen depleted 
condition. A similar result was reported by Zemke-White et al. [27], in which they had analysed 4 macroalgae, namely, Enteromorpha intestinalis, Ulva rigida, Porphyra sp., and Polysiphonia strictissima and found that at $\mathrm{pH} 2.0$ for $60 \mathrm{~min}$ the cell wall pore size of all four algal species increased up to at least $13.5 \mathrm{~nm}$ more than the normal cell wall size $(8.8 \mathrm{~nm})$. In the present study, after $2 \mathrm{~h}$ of treatment, the amount of oil yield was found to be constant. Hence we concluded that the algal cell wall lysed when treated for $2 \mathrm{~h}$ at a low $\mathrm{pH}$ 2 , the porosity of cell wall increased, and intracellular lipid got released. Also this finding was supported by Harun and Danquah [28]. They had reported that acid pretreatment process was most suitable for hydrolyzing the cell wall of Chlorococcum humicola to release and convert the polysaccharides, entrapped in microalgal cell wall, into simple sugars for ethanol production.

Ultrasonication is a simple physical method for disrupting $N$. oculata. The cells grown in normal nutrition condition were exposed to various time periods, namely, 5 , 10 , and 15 min and a maximum of $30.12 \%$ oil was extracted at 15 min pretreatment. Similarly nitrogen depleted cells, when ultrasonicated at the above mentioned time intervals, showed higher extraction efficiency of $45.77 \%$ at a pretreatment time of $15 \mathrm{~min}$. Higher the processing time, higher would be the oil yield. In contrast to the present study, Lee et al. [10] observed that ultrasonication resulted in least efficiency for Botryococcus sp. Suganya and Renganathan [8] reported that, through ultrasonication, higher extraction efficiency was achieved 2.25 times higher than that of direct extraction of oil from Ulva lactuca. Ultrasonication is one of the major pretreatments of algal cells for extracting oil; hence higher physical stress due to vibration on prolonged exposure, to extensive release of oil because of cell disruption, enhances the yield of oil for biodiesel production.

Autoclaving of microalgal cells was carried out for extraction of oil at various time intervals 10,20 , and $30 \mathrm{~min}$ at $121^{\circ} \mathrm{C}$. Higher yield of oil was obtained from nitrogen depleted cells than the normally cultivated microalgal cells. At high thermal treatment, at $30 \mathrm{~min}$, maximum amount of oil (28.81\%) was obtained for normal cultures. Likewise for the nitrogen depleted cells the oil content was found to be at its maximum $(43.90 \%)$ at $30 \mathrm{~min}$. Autoclaving was found to be one of the most efficient methods yielding $7.88 \%$ of oil from Ulva lactuca by disrupting the membranes of the cells [8]. Lee et al. [10] also reported that extraction of oil from Chlorella vulgaris was at its maximum of $7.9 \%$ on autoclaving. Therefore, the higher the time of autoclaving at a high temperature, the higher the oil yield.

The effect of $40 \% \mathrm{NaCl}$ was studied by subjecting the normally nourished and nitrogen starved cells at different time intervals. This higher osmotic shock resulted in cell lysis due to susceptibility of cell membrane of microorganisms. For normal cells $24 \mathrm{~h}$ the highest oil content was obtained for $48 \mathrm{~h}$ as $26.49 \%$. Similarly, under nitrogen depleted cells the maximum yield oil was $40.56 \%$ at $48 \mathrm{~h}$. For determination of optimistic time for oil extraction with $\mathrm{NaCl}$, the cells were treated above $48 \mathrm{~h}$ till $72 \mathrm{~h}$, but the amount of oil remained constant. Hence, $48 \mathrm{~h}$ was found to be an optimum extraction time for $40 \% \mathrm{NaCl}$ treatment. However, the osmotic shock is a simple procedure for oil extraction but it did not show much disruption effect on microalgal cells and required longer time duration. The current result was supported by the work of Lee et al. [10] for treating microalgal species, C. vulgaris and Scenedesmus sp. for $48 \mathrm{~h}$.

Dejoye et al. [29] reported that extraction of oil from microalgae with microwave pretreated microalgae systematically presented higher yields. But in contrast, in this study, microwave pretreated method did not significantly affect cell disruption. Microwave assisted treatment was performed at 5,10 , and $15 \mathrm{~min}$ for oil extraction by cell distortion. The maximum oil content using this method was found to be $26.51 \%$ at $5 \mathrm{~min}$ for normal cells and for nitrogen depleted cells it was $41.28 \%$ at $5 \mathrm{~min}$. A decline in oil content was experienced as the time of exposure prolonged. A similar result was found in a previous study that microalgal lipid extraction efficiency was not effective and the oil extracted from microalgae by microwave method became volatile during disruption and extraction process [6] (Table 3).

Higher lipid concentration represented the disruption efficiency in this study and nitrogen depletion enhanced oil content on marine microalgae $N$. oculata, which was compared with the control. Among several methods for pretreating $N$. oculata for oil extraction, the enzymatic method gave maximum efficiency for normal culture and nitrogen depleted culture and also revealed that this method was the best for microalgal cell wall lysis. Acid pretreatment gave second maximum yield. Poor efficiency was shown by ultrasonication, autoclaving, microwave oven, and $40 \%$ $\mathrm{NaCl}$ pretreatment. Similar results were also found in Zheng et al. [6], who had studied various pretreatment on fresh water microalgae, C. vulgaris, showing higher effects of enzymes like lysozyme and cellulose on oil extraction by cell disruption.

In addition, from an extensive literature survey, it was noted that nowadays enzymatic extraction has been widely used in extraction of bioactive compounds from plant based materials. It is more attractive, with advantages like shorter extracting time, less pollution, higher extraction yield, and less decomposition of target compounds [30]. Moreover, enzymatic hydrolysis is specific, gentle and has specific effect on cell wall of algae especially on hemicelluloses and saccharides and accelerates the migration of bioactive compounds. Compared with conventional methods, it utilizes less energy and gave higher extraction yield [30]. Zheng et al. [6] stated that the enzymatic process could be worked at low temperature and could prevent the oxidation of oil, thus improving the biodiesel quality.

3.6. SEM Analysis of Algal Cells. For direct evidence on different pretreatment methods on cell wall damage, microalgal cells can be observed by microscopic study (Figure 4). The undamaged cells of $N$. oculata (Figure 4(a)) showed intact structures and had no indication of cell lysis. In addition, acid treatment $1 \mathrm{M} \mathrm{HCl}$ totally disrupted the morphology of microalgal structure appearing completely broken cells under Scanning Electron Microscope (Figure 4(b)). Next to the acid 
TABLE 3: Lipid content at various pretreatment processes of N. oculata under nitrogen rich and nitrogen starved conditions.

\begin{tabular}{|c|c|c|c|}
\hline Various pretreatment & Pretreatment time $(\mathrm{min} / \mathrm{h})$ & Normal growth & Nitrogen depleted growth \\
\hline Control & & 26.43 & 40.52 \\
\hline \multirow{3}{*}{ Acid } & $1 \mathrm{~h}$ & 31.23 & 48.38 \\
\hline & $2 \mathrm{~h}$ & 33.18 & 54.26 \\
\hline & $3 \mathrm{~h}$ & 33.18 & 54.26 \\
\hline \multirow{3}{*}{ Enzyme } & $8 \mathrm{~h}$ & 29.38 & 45.28 \\
\hline & $10 \mathrm{~h}$ & 30.62 & 48.52 \\
\hline & $12 \mathrm{~h}$ & 32.74 & 51.68 \\
\hline \multirow{3}{*}{ Ultrasonication } & $5 \mathrm{~min}$ & 28.14 & 44.16 \\
\hline & $10 \mathrm{~min}$ & 29.32 & 45.24 \\
\hline & $15 \mathrm{~min}$ & 30.12 & 45.77 \\
\hline \multirow{3}{*}{ Autoclave } & $10 \mathrm{~min}$ & 27.68 & 42.39 \\
\hline & $20 \mathrm{~min}$ & 28.06 & 43.38 \\
\hline & $30 \mathrm{~min}$ & 28.81 & 43.90 \\
\hline \multirow{3}{*}{ Microwave oven } & $5 \min$ & 26.51 & 41.28 \\
\hline & $10 \mathrm{~min}$ & 22.88 & 35.36 \\
\hline & $15 \mathrm{~min}$ & 16.79 & 23.21 \\
\hline \multirow{3}{*}{$40 \% \mathrm{NaCl}$} & $24 \mathrm{~h}$ & 26.45 & 40.54 \\
\hline & $48 \mathrm{~h}$ & 26.49 & 40.56 \\
\hline & $72 \mathrm{~h}$ & 26.49 & 40.56 \\
\hline
\end{tabular}

TABLE 4: Fatty acid composition of N. oculata FAME.

\begin{tabular}{|c|c|c|c|c|c|}
\hline Lipid number & Common name & Systematic name & Molecular structure & Fatty acid $\left(\mathrm{N}^{+}\right) \%$ & Fatty acid $\left(\mathrm{N}^{-}\right) \%$ \\
\hline $\mathrm{C} 14: 0$ & Myristic acid & Tetradecanoic acid & $\mathrm{C}_{12} \mathrm{H}_{24} \mathrm{O}_{2}$ & 9.86 & 8.94 \\
\hline $\mathrm{C} 16: 0$ & Palmitic acid & Hexadecanoic acid & $\mathrm{C}_{16} \mathrm{H}_{32} \mathrm{O}_{2}$ & 19.39 & 13.83 \\
\hline C18:0 & Stearic acid & Octadecanoic acid & $\mathrm{C}_{18} \mathrm{H}_{36} \mathrm{O}_{2}$ & 10.76 & 9.79 \\
\hline $\mathrm{C} 18: 1$ & Oleic acid & 9-Octadecenoic acid & $\mathrm{C}_{18} \mathrm{H}_{34} \mathrm{O}_{2}$ & 35.21 & 44.68 \\
\hline $\mathrm{C} 18: 2$ & Linoleic acid & 9,12-Octadecadienoic acid & $\mathrm{C}_{18} \mathrm{H}_{32} \mathrm{O}_{2}$ & 8.15 & 6.92 \\
\hline C20:0 & Arachidic acid & Eicosanoic acid & $\mathrm{C}_{18} \mathrm{H}_{30} \mathrm{O}_{2}$ & 16.62 & 15.84 \\
\hline
\end{tabular}

$\mathrm{N}^{+}$: presence of nitrogen, $\mathrm{N}^{-}$: absence of nitrogen.

lysis the effective cell disruption happened with enzymatic (cellulase) and ultrasonic disruption (Figures 4(c) and 4(d)).

3.7. Fatty Acid Composition Analysis by GC-MS. The major fatty acid composition of the extracted oil from the different cell disruption methods was determined using GC-MS system (Table 4).

Our experiments found out that various pretreatment methods had beneficial effects on the cell disruption of marine microalga $N$. oculata to extract oilwithout changing fatty acid composition. From the retention time obtained by GC-MS, peak values were analysed and observed as lauric acid (C12:0), palmitic acid (C16:0), stearic acid (C18:0), oleic acid (C18:1), linoleic acid (C18:2), and arachidic acid (C20:0), which were commonly found in N. oculata oil (Table 2). However, under nitrogen starvation condition the lipid content not only doubled but also gradually changed the fatty acid composition of microalgae [3, 31]. In N. oculata, the oleic acid content increased from $35.21 \%$ to $44.68 \%$. This result was in better agreement with previous study conducted by Zhila et al. [32].

Unsaturated fatty acids have been reported as reasonable balance of fuel properties [6]. The chain length of fatty acids in N. oculata was observed between $\mathrm{C} 12$ and C20. In a previous report, it was stated that the fatty acids with maximum of $\mathrm{C} 16$ and $\mathrm{C} 18$ series were recognized as the most common components of biodiesel [33]. Therefore, fatty acids from $N$. oculata were more applicable for producing high quality of biofuel, since it contained high content of $\mathrm{C} 16$ (palmitic acid) and C18 (oleic acid).

\section{Conclusion}

This paper demonstrated the utility of various pretreatment protocols to extract lipids by cell disruption. Amongst all the procedures, acid hydrolysis proved to be the appropriate method. Additionally, it was found that cells when under stressed condition, that is, nitrogen depleted state, produced 


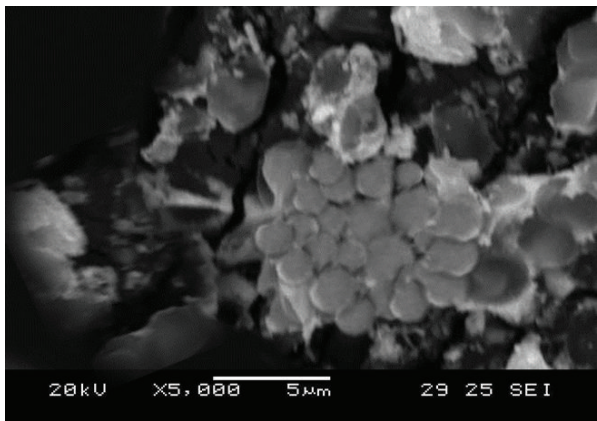

(a)

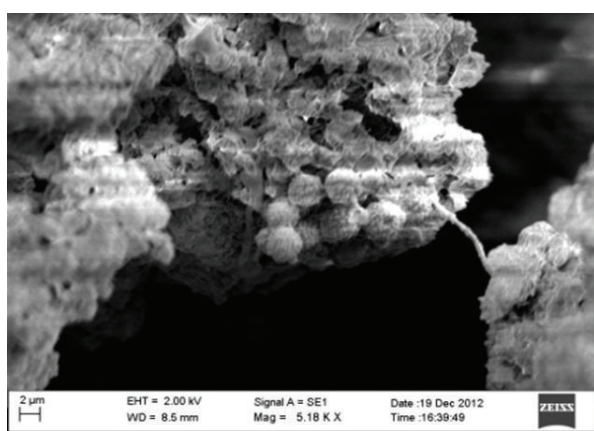

(c)

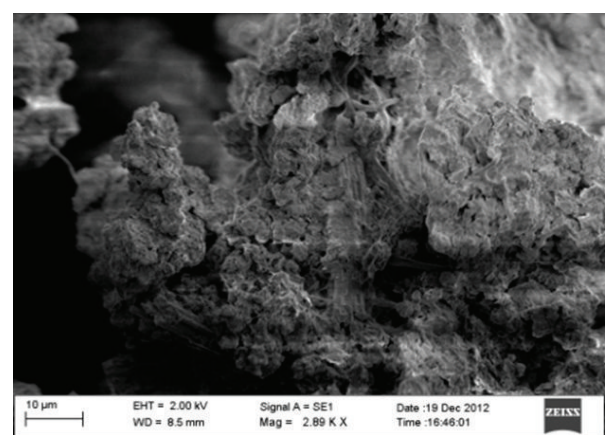

(b)

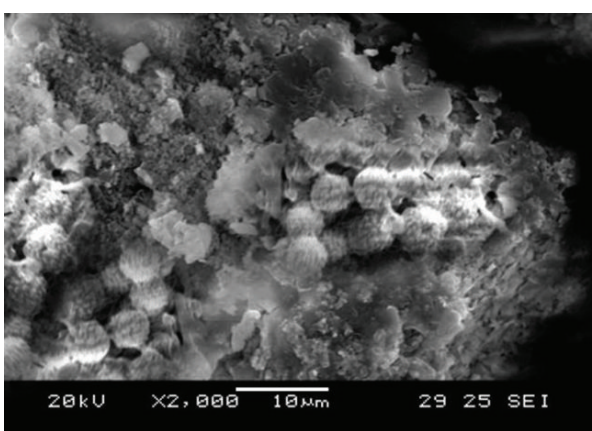

(d)

Figure 4: Scanning electron microscopic images of morphological analysis of various pretreatment processes. (a) Control, (b) acid pretreatment, (c) enzyme pretreatment, and (d) ultrasonication.

lipids at a higher rate due to the reversion of carbohydrate, protein metabolism to that of lipid, which was clearly depicted by FT-IR spectral analysis. This technique could be used for the large scale production and utilize lipids to generate biodiesel.

\section{Conflict of Interests}

The authors claim no conflict of interests.

\section{References}

[1] P. Schlagermann, G. Gottlicher, R. Dillschneider, R. RoselloSastre, and C. Posten, "Composition of algal oil and its potential as biofuel," Journal of Combustion, vol. 2012, Article ID 285185, 14 pages, 2012.

[2] H.-C. Chen, H.-Y. Ju, T.-T. Wu et al., "Continuous production of lipase-catalyzed biodiesel in a packed-bed reactor: optimization and enzyme reuse study," Journal of Biomedicine and Biotechnology, vol. 2011, Article ID 950725, 6 pages, 2011.

[3] A. Widjaja, C.-C. Chien, and Y.-H. Ju, "Study of increasing lipid production from fresh water microalgae Chlorella vulgaris," Journal of the Taiwan Institute of Chemical Engineers, vol. 40, no. 1, pp. 13-20, 2009.

[4] M. A. Rodrigues and E. P. S. Bon, "Evaluation of chlorella (Chlorophyta) as source of fermentable sugars via cell wall enzymatic hydrolysis," Enzyme Research, vol. 2011, Article ID 405603, 5 pages, 2011.

[5] E. Ryckebosch, K. Muylaert, and I. Foubert, "Optimization of an analytical procedure for extraction of lipids from microalgae,"
Journal of the American Oil Chemists' Society, vol. 89, no. 2, pp. 189-198, 2012.

[6] H. Zheng, J. Yin, Z. Gao, H. Huang, X. Ji, and C. Dou, "Disruption of Chlorella vulgaris cells for the release of biodieselproducing lipids: a comparison of grinding, ultrasonication, bead milling, enzymatic lysis, and microwaves," Applied Biochemistry and Biotechnology, vol. 164, no. 7, pp. 1215-1224, 2011.

[7] P. Mercer and R. E. Armenta, "Developments in oil extraction from microalgae," European Journal of Lipid Science and Technology, vol. 113, no. 5, pp. 539-547, 2011.

[8] T. Suganya and S. Renganathan, "Optimization and kinetic studies on algal oil extraction from marine macroalgae Ulva lactuca," Bioresource Technology, vol. 107, pp. 319-326, 2012.

[9] K. Sander and G. S. Murthy, "Enzymatic degradation of microalgal cell walls," in Proceedings of the American Society of Agricultural and Biological Engineers Annual International Meeting (ASABE '09), Paper Number: 1035636, pp. 2489-2500, June 2009.

[10] J.-Y. Lee, C. Yoo, S.-Y. Jun, C.-Y. Ahn, and H.-M. Oh, "Comparison of several methods for effective lipid extraction from microalgae," Bioresource Technology, vol. 101, no. 1, pp. S75-S77, 2010.

[11] G. Jin, F. Yang, C. Hu, H. Shen, and Z. K. Zhao, "Enzymeassisted extraction of lipids directly from the culture of the oleaginous yeast Rhodosporidium toruloides," Bioresource Technology, vol. 111, pp. 378-382, 2012.

[12] E. G. Bligh and W. J. Dyer, "A rapid method of total lipid extraction and purification," Canadian Journal of Biochemistry and Physiology, vol. 37, no. 8, pp. 911-917, 1959.

[13] N. G.-E. Mohammady, C. W. Rieken, S. R. Lindell et al., "Age of nitrogen deficient microalgal cells is a key factor for maximizing 
lipid content," Research Journal of Phytochemistry, vol. 6, no. 2, pp. 42-53, 2012.

[14] C.-H. Su, C.-C. Fu, Y.-C. Chang et al., "Simultaneous estimation of chlorophyll a and lipid contents in microalgae by three-color analysis," Biotechnology and Bioengineering, vol. 99, no. 4, pp. 1034-1039, 2008.

[15] O. H. Lowry, N. J. Rosebrough, A. L. Farr, and R. J. Randall, "Protein measurement with the Folin phenol reagent," The Journal of Biological Chemistry, vol. 193, no. 1, pp. 265-275, 1951.

[16] C. Yeesang and B. Cheirsilp, "Effect of nitrogen, salt, and iron content in the growth medium and light intensity on lipid production by microalgae isolated from freshwater sources in Thailand," Bioresource Technology, vol. 102, no. 3, pp. 30343040, 2011.

[17] M. Alsull and W. M. W. Omar, "Responses of Tetraselmis sp. and Nannochloropsis sp. isolated from Penang National Park coastal waters, Malaysia, to the combined influences of salinity, light and nitrogen limitation," in Proceedings of the International Conference on Chemical, Ecology and Environmental Sciences (ICEES '12), pp. 142-145, Bangkok, Thailand, March 2012.

[18] C. M. Beal, M. E. Webber, R. S. Ruoff, and R. E. Hebner, "Lipid analysis of Neochloris oleoabundans by liquid state NMR," Biotechnology and Bioengineering, vol. 106, no. 4, pp. 573-583, 2010.

[19] D. Feng, Z. Chen, S. Xue, and W. Zhang, "Increased lipid production of the marine oleaginous microalgae Isochrysis zhangjiangensis (Chrysophyta) by nitrogen supplement," Bioresource Technology, vol. 102, no. 12, pp. 6710-6716, 2011.

[20] G. Ahlgren and P. Hyenstrand, "Nitrogen limitation effects of different nitrogen sources on nutritional quality of two freshwater organisms, Scenedesmus quadricauda (Chlorophyceae) and Synechococcus sp. (Cyanophyceae)," Journal of Phycology, vol. 39, no. 5, pp. 906-917, 2003.

[21] M. Hoffmann, K. Marxen, R. Schulz, and K. H. Vanselow, "TFA and EPA productivities of Nannochloropsis salina influenced by temperature and nitrate stimuli in turbidostatic controlled experiments," Marine Drugs, vol. 8, no. 9, pp. 2526-2545, 2010.

[22] S. Elumalai, V. Prakasam, and R. Selvarajan, "Optimization of abiotic conditions suitable for the production of biodiesel from Chlorella vulgaris," Indian Journal of Science and Technology, vol. 4, no. 2, pp. 91-97, 2011.

[23] U. Pick and T. Rachutin-Zalogin, "Kinetic anomalies in the interactions of Nile red with microalgae," Journal of Microbiological Methods, vol. 88, no. 2, pp. 189-196, 2012.

[24] M. M. Phukan, R. S. Chutia, B. K. Konwar, and R. Kataki, "Microalgae Chlorella as a potential bio-energy feedstock," Applied Energy, vol. 88, no. 10, pp. 3307-3312, 2011.

[25] N. Rukminasari, "Effect of nutrient depletion and temperature tressed on growth and lipid accumulation in marine-green algae Nannochloropsis sp," American Journal of Research Communication. In press.

[26] C.-C. Fu, T.-C. Hung, J.-Y. Chen, C.-H. Su, and W.-T. Wu, "Hydrolysis of microalgae cell walls for production of reducing sugar and lipid extraction," Bioresource Technology, vol. 101, no. 22, pp. 8750-8754, 2010.

[27] W. L. Zemke-White, K. D. Clements, and P. J. Harris, "Acid lysis of macroalgae by marine herbivorous fishes: effects of acid $\mathrm{pH}$ on cell wall porosity," Journal of Experimental Marine Biology and Ecology, vol. 245, no. 1, pp. 57-68, 2000.

[28] R. Harun and M. K. Danquah, "Influence of acid pre-treatment on microalgal biomass for bioethanol production," Process Biochemistry, vol. 46, no. 1, pp. 304-309, 2011.
[29] C. Dejoye, M. A. Vian, G. Lumia, C. Bouscarle, F. Charton, and F. Chemat, "Combined extraction processes of lipid from Chlorella vulgaris microalgae: microwave prior to supercritical carbon dioxide extraction," International Journal of Molecular Sciences, vol. 12, no. 12, pp. 9332-9341, 2011.

[30] S. Li, H. Zhang, D. Han, and K. H. Row, "Optimization of enzymatic extraction of polysaccharides from some marine algae by response surface methodology," Korean Journal of Chemical Engineering, vol. 29, no. 5, pp. 650-656, 2012.

[31] G. Huang, F. Chen, D. Wei, X. Zhang, and G. Chen, "Biodiesel production by microalgal biotechnology," Applied Energy, vol. 87, no. 1, pp. 38-46, 2010.

[32] N. O. Zhila, G. S. Kalacheva, and T. G. Volova, "Effect of nitrogen limitation on the growth and lipid composition of the green alga Botryococcus braunii Kütz IPPAS H-252," Russian Journal of Plant Physiology, vol. 52, no. 3, pp. 311-319, 2005.

[33] Q. Lin, N. Gu, G. Li, J. Lin, L. Huang, and L. Tan, "Effects of inorganic carbon concentration on carbon formation, nitrate utilization, biomass and oil accumulation of Nannochloropsis oculata CS 179," Bioresource Technology, vol. 111, pp. 353-359, 2012. 

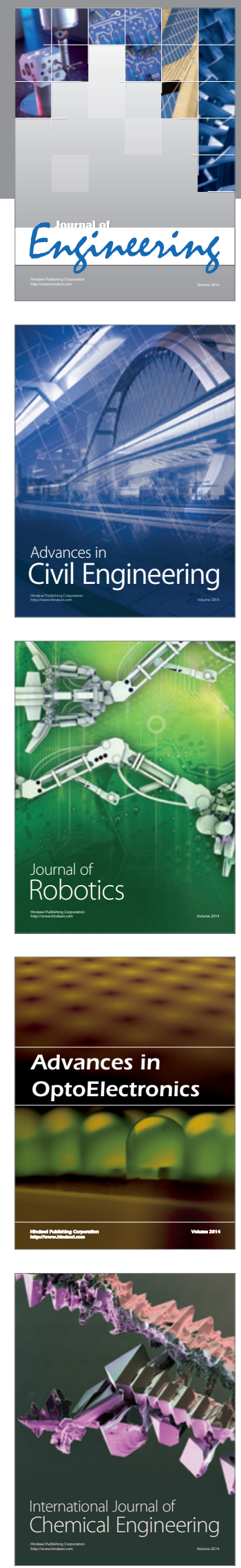

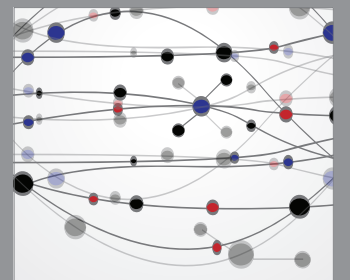

The Scientific World Journal
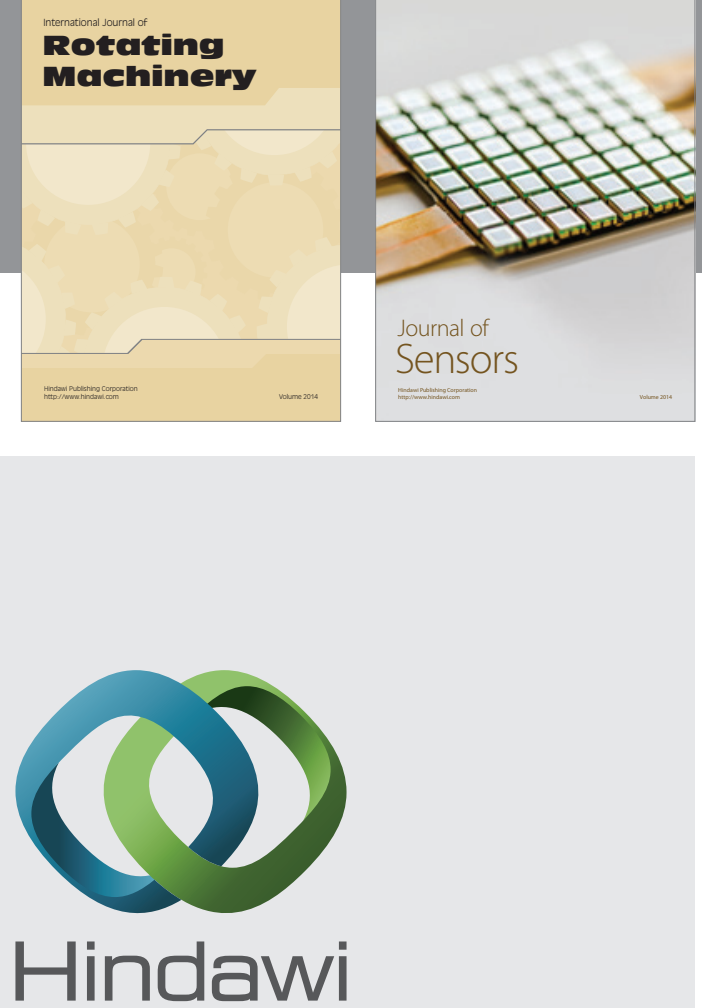

Submit your manuscripts at http://www.hindawi.com
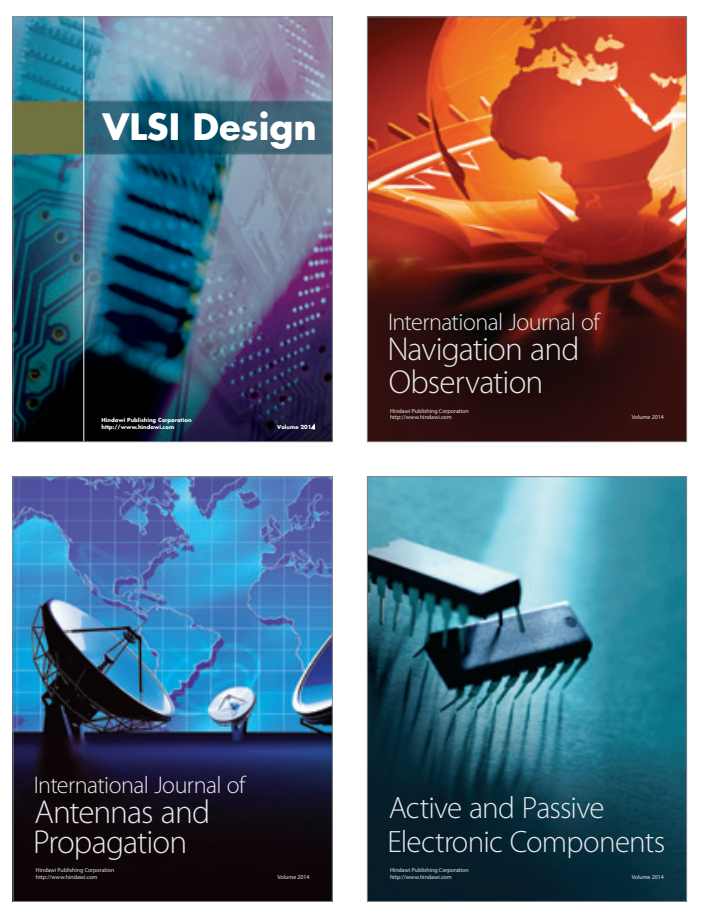
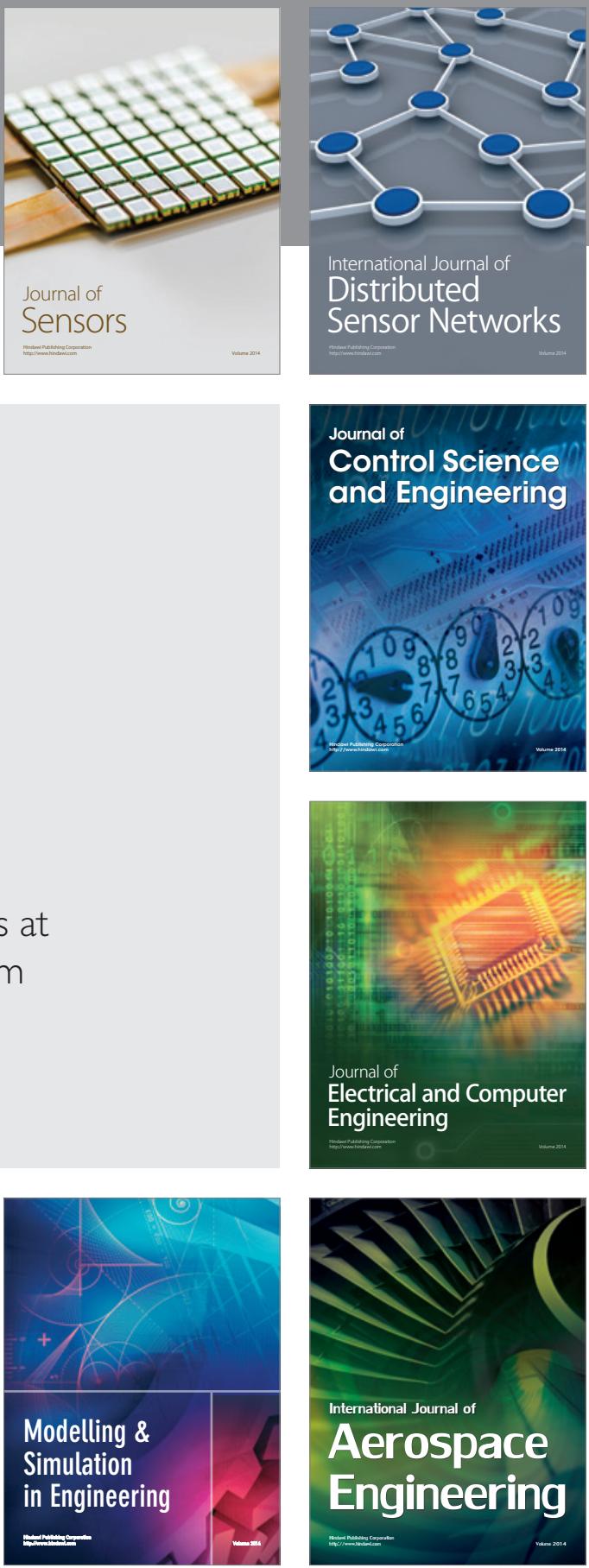

Journal of

Control Science

and Engineering
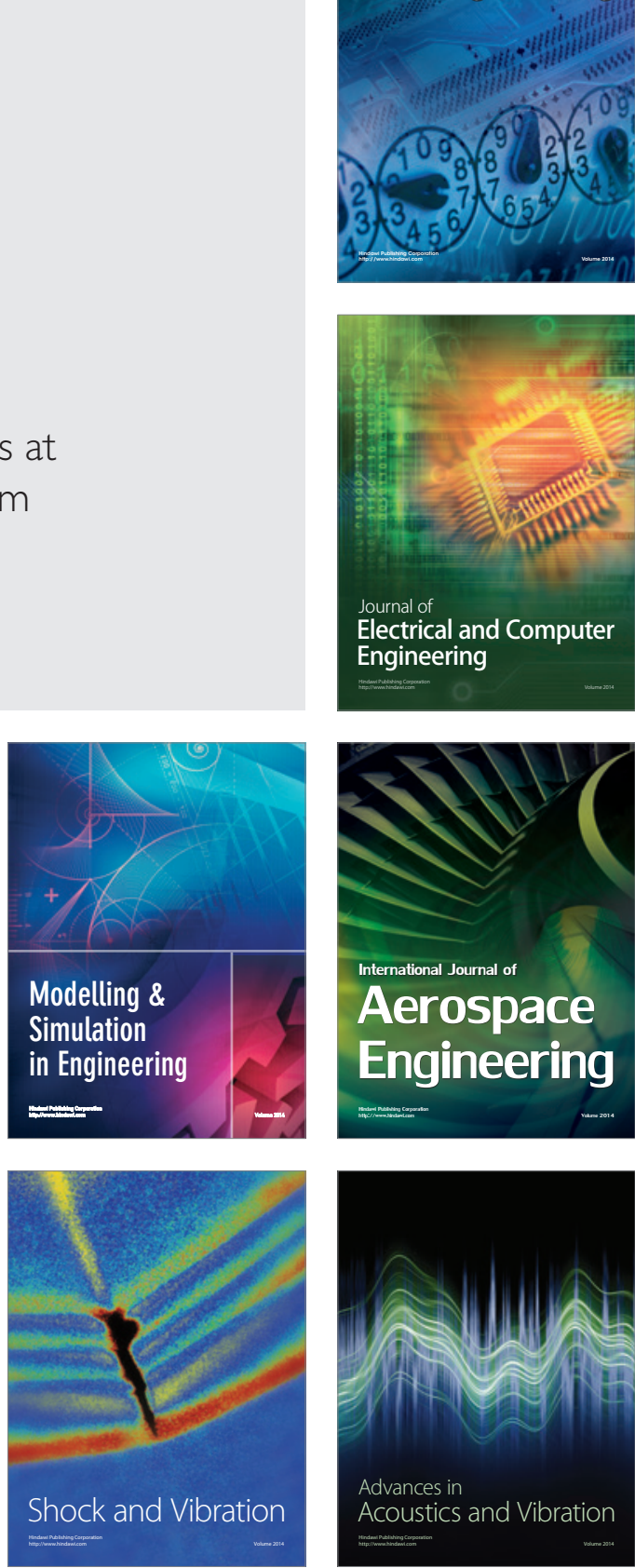